\title{
Globalization and the thought of unity in diversity of Badiuzzaman Said Nursi in the light of his magnum opus Risala-i Nur
}

\author{
Mohammad Ajmal \\ Centre of Arabic and African Studies, Jawaharlal Nehru University New Delhi \\ E-mail:ajmalmohammad114@gmail.com
}

\begin{abstract}
Badiuzzaman Said Nursi had always looked at the world as one component glorifying the one creator and testifying to His greatness. The universality he believed in, came into contradiction with the universality that results from globalization as it is generally understood and illustrated. People of economically less auspicious countries become themselves agents of globalization in their own places. This is why the effects of globalization are more harmful than those of colonialism. Globalization recruits its soldiers from among people it invades and expands to swallow the remnants of their culture and selfesteem by making them follow the model of those who are more powerful and who possess more.
\end{abstract}

Badiuzzaman Said Nursi selalu memandang dunia sebagai salah satu komponen untuk memuliakan Sang Pencipta dan menyaksikan kebesaran-Nya. Universalitas yang dipercayainya, berlawanan dengan universalitas yang dihasilkan dari globalisasi seperti yang umum dipahami dan digambarkan. Masyarakat dari Negara-negara yang secara ekonomis kurang beruntung menjadikan diri mereka 
sendiri sebagai agen globalisasi di negara mereka sendiri. Inilah sebabnya mengapa efek globalisasi lebih berbahaya daripada kolonialisme. Globalisasi merekrut tentaranya dari kalangan orang-orang yang menjadi sasaran serangnya dan menelan sisa-sisa kebudayaan mereka serta harga diri dengan membuat mereka mengikuti model mereka yang lebih kuat dan memiliki kelebihan.

Keywords: Globalization; Risala-i Nur; Diversity; Universality

\section{Introduction}

The phenomenon of globalization is indeed controversial with regard to its meaning and impact on the world. Both those in favor or opposition to globalization tend to form a perspective in accordance to their own particular ideology. However, these perspectives may begin to shape the dialogue regarding globalization; they serve only as an introduction to the far larger dimension of globalization. It is incumbent upon us to consider the variant approaches and perspectives, with consideration to the vast world view of Islam. Globalization has popularly been understood as:

Globalization is a gradual and ongoing expansion of interaction process, forms of organization and forms of cooperation outside the traditional spaces defined by sovereignty. ${ }^{1}$ It is a historical process which involves more than simply economic and other linkages between separate nation-states or national economies. It is analytically distinct from interdependence or inter-national relations. The later denotes growth in connections and linkages between sovereign entities, whereas the globalization process involves the interpretation of people and ideas, not just the movement of goods and capital.

During the modernization era of the 1960s, for instance, cultural flows were unidirectional, moving from the developed West to the developing

1 John Esposito, "Religion and Global Affairs: Political Challenges," SAIS Review Vol. 18, No. 2 (1998), 19. 
non-Western countries, which led critics to describe it variously as "cultural dumping", "colonization of the minds of the periphery" or "cultural enslavement". By contrast, globalization refers to faster and multi-directional cultural flows. It celebrates cultural diversity, whereas the modernization era prioritized cultural unity. ${ }^{2}$

This process has effects on the environment, on culture, on political systems, on economic development and prosperity, and on human physical well-being in societies around the globe" ${ }^{3}$

\section{Nursi's approach to unity in diversity}

In the light of Said Nursi's thought, the example of living in unity in diversity for the entire mankind is as the entire Universe and the creation of the Creator is diverse yet it is in harmony with each other by His Grace the unity just as you see in your own body, all organs are different, and are made of billions of small different cells, and have different functions and yet are united together to make different organ systems with different functions.

Badiuzzaman Said Nursi had always looked at the world as one component exalting the one creator and testifying to His greatness. ${ }^{4}$ The universality he believed in, came into contradiction with the universality that results from globalization.

Said Nursi's ideas of unity in diversity mostly attempt to revitalize religious life amongst Turkish people and to expand it to non-muslim world. After the advent of Kamal Attaturk in Turkish rule, Islam has been overshadowed by secularism. However, Islamic revivalism was also seen in

\footnotetext{
${ }^{2}$ Roland Robertson, Globalization, Social Theory and Global Culture, London: Sage Publication, 1997, 18.

3 Peter Martin, Hans and Harold Showman, فخ العولمة (Piercing Globalization), Kuwait: Dār al-Ma'rifa, 2003, 44.

${ }^{4}$ Ian Markham and Ibrahim Ozdemir, Globalization, Ethics and Islam: the Case of Bediuzzaman Said Nursi, np.: Ashgate Publishing, Ltd., 2005, 113.
} 
many other parts of the world including Turkey, with its particular vitality and specific goals. This revivalism was generally driven by the necessity of liberating Muslims from alien ideologies brought by Western colonialists who occupied their lands. These ideologies, including secularism, were thought to have been thwarting from observing properly the Muslims especially who practice and perform the customs and rituals of the tenets of Islam.

It is an ironic; the people of economically less auspicious countries become themselves agents of globalization in their own places. Therefore the effects of globalization are more harmful than those of colonialism. Globalization recruits its soldiers from among people it invades and expands to consume the remnants of their culture and self-esteem by making them follow the model of those who are more powerful and who possess more.

\section{Globalization vis-à-vis Risala-i Nur of Nursi}

In the Risala-i Nur, Said Nursi on the one hand attempted to reply to the challenges of modernity, in other word globalization, and on the other, offering a new understanding of Divine revelation, he emphasized above all else the peace, harmony, synchronization of masses, and beauty of the world, which he called the book of the universe, and in this way set out to demonstrate God's existence together with all His Most Beautiful Names.

In the light of Nursi's thought, he has divided the West and "Europe" into two categories one is western multiculturalism and the second is globalization. The first is compassionate, descent, virtuous and just and the other which is unjust, decadent and exploitative.

Likewise Nursi has shown the way and has left the choice to the masses, whether they choose the path of clash (as some have done so already) or choose the path of dialogue and mutual respect (as many are doing so). 
Globalization, as mentioned earlier, is a product of modernization, which is closely associated with the transformation of western societies over the past few centuries. As a process of social change, the development of Western societies has been built upon the principle of separation of religion from state implying that the Church plays no active role in the evolution of the socio-economic and political formation of these countries. Religion is limited only to the preservation of individual freedom of worship, whereas the formulation of legal, social, political and matters concerning the society at large are entrusted to elected members of the society.

The inclusive nature of the Risala-i Nur, aptly addresses the inhabitants of the world, which in itself is a powerful factor for meaningful interaction. Nursi declares that "For conquering the civilized thought is through persuasion, not through force as though they were savages who understand nothing. We are devotees of love; we do not have time for enmity." ${ }^{5}$ This is true not only for non-Muslims but also for different factions of Muslim societies who are sometimes at odds with one another. Today, while interfaith dialogue is understood as a necessity to build bridges and understand "the other" in order to develop peaceful coexistence and cooperation for a better world, we must confront the reality that Muslims have lagged behind their engagement of intra-faith dialogue, which is what our communities desperately need in order to preserve the unity of the Muslim throughout the world. The unfriendliness and hostility of Muslims to commit to intra-faith dialogue has gone exponentially far during the last decades. ${ }^{6}$ So much so that various Muslim societies and

${ }^{5}$ Ian S. Markham, Engaging with Bediuzzaman Said Nursi: a Model of Interfaith Dialogue, np.: Ashgate Publishing, Ltd., 2009, 67.

${ }^{6}$ Adib Ibrahim El Dabbagh, شركة سوزلز للنشر رسحيد النورسي رجل الإبمان في محنة الكفز والطغنيان, 2003, 36 . 
communities are no longer able to understand, appreciate or communicate with each other. These barriers yield tension and severe conflicts.

\section{Divine power vis-à-vis human nature}

What Nursi affirms here is that man is not capable to conduct his worldly affairs by himself alone because of his weakness and that without spiritual guidance and Divine interference man is ultimately the loser. He goes on to say: "In regard to his acts and deeds and his labor man is a weak animal, an impotent creature. The extent of his power of disposal and ownership in this respect is so narrow that it is no greater than as far as his hand can reach." To depend on the commandments of God to furnish man's path in life of this world means that the message of Islam is universal in the sense that all mankind was invited to follow the same path drawn by the same Creator. The Islamic mission is to free man from all forms of worldly worship, oppressions, slavery, and exploitation that cause the degradation of man status as God's vicegerent. In the Hereafter man will be judged not on the basis of color, race or religion but on the basis of Taqwa or good deeds. Globalization on the other hand, means to change the role of religion in society by imposing a global set of rules to be applied by all.

\section{Nursi's warning to Muslim sects}

Even Nursi by addressing the two major Muslim sects Sunni's and Alavi's has painstakingly called on" o Sunnis who are the People of Truth, and Alavis i.e. Shi'a sectarians, whose way is the love of the Prophet's Family! Put an end to this meaningless, disloyal, unjust, and harmful dispute between each other. Otherwise, the atheistic current, which is now so influential, will make one of you a tool against the other, and use the one to crush against the other. And after defeating the one, it will destroy the tool. Since you are believers in Divine Unity, it is essential to leave aside 
unimportant matters, which force division while there are a hundred fundamental sacred bonds between you, which command brotherhood and unity. ${ }^{?}$

The Risala-i Nur put due stress upon the underlying differences between various groups of Muslims. Instead, Nursi makes iman (belief) the core area of Islam. He leaves aside the details rooted in the diverse practices of figh (Islamic law or jurisprudence) and any slight doctrinal distinctions which do not contradict with the basics of Tawhid. The fundamental approach of the Risala-i Nur is to gather Muslims together in their entirety, upon common grounds. ${ }^{8}$ This broad and all-embracing outlook of the Risala-i Nur is somewhat of a social plaster for the entire mankind in general and a genuine asset for the Muslims in particular.

Moreover, in the assessment of the conditions of this globalized modern world, the Risala-i Nur promotes positive action-otherwise understood as a non-violent way of serving God. The Risala-i Nur's power comes from a solid methodology of proving the foundational pillars of faiths such as the existence of God, theory of monotheism, Resurrection and the Life Hereafter etc. The Risala-i Nur is dynamically able to address the spectrum of modern human values such as unity in diversity, freedom of thought and freedom of religion, which only serves to strengthen its legitimacy. Yet strength of the Risala-i Nur is its key characteristic of refraining from politics. Although Said Nursi had actively been interested in politics in his early life, he recognized its uselessness and danger and subsequently withdrew from any involvement in that realm. ${ }^{9}$ Eloquent

\footnotetext{
${ }^{7}$ Bediuzzaman Said Nursi, Risale-i-Nur: Flashes Collection, Istanbul: Sozler Publications, 2004, 43.

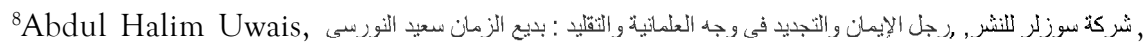
2003, 121.

${ }^{9}$ Ibrahim Abu Rabi, Spiritual Dimensions of Bediuzzaman Said Nursi's Risale-i Nur, Albany: State University of New York Press, 2008, 79.
} 
as ever, Nursi explains why he chose to refrain from politics in the latter years of his life. Through the use of a very interesting analogy, he states:

In any event, service of the Quran prohibits me from thinking of socio-political life. It is just like that: human life is a journey. I saw at this time through the light of the Quran that the way has entered into a quagmire. The caravan of mankind is stumbling forward in stinking, filthy mud. Part of it is travelling a safe way. Another part has found certain means to save itself as far as is possible from the muddy swamp. But the great majority is travelling in darkness in the midst of it. Twenty per cent suppose the filthy mud to be musk and ambergris because they are drunk, and are smearing it over their faces and eyes; they stumble on till they drown in it. However, eighty per cent understand it is a swamp and realize it is stinking and filthy, but they are bewildered and cannot discern the safe way. ${ }^{10}$ Nursi has placed just two points to solve this crisis.

The First: to bring the drunken twenty per cent to their senses with a club. The Second: to point out the safe way to the bewildered by showing them a light, and in Turkey that was the Democrat Party Era during 1950 - 1960 and with the last ten years of his life.

And he further says: "I seek refuge with God from Satan and from politics" and threw away the club of politics; I embraced the light with both hands. I saw that among the political movements are lovers of those lights in both the opposition and the supporters. No side or group should cast aspersions on or hold back from the lights of the Quran that are held up, or from the teachings of the Quran, which are far superior to all political currents and partisanship and are exempt from and free of all their biased considerations. Only satans in human form or animals in

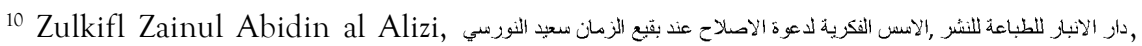
2002, 112. 
human dress would do so since they imagine irreligion and atheism to be politics and support them. ${ }^{11}$

"Since religion enjoys a different status in different places around the globe, the concept of religion itself is forced to undergo transformation as part of the process of globalization. These processes, however, should not be understood merely as a breakdown of tradition, and which must therefore be inhibited. The globalization processes do not proceed in specific fields or areas, but function as a rearrangement of world systems". ${ }^{12}$

\section{Risala-i Nur vis-à-vis globalization}

Secularisation on the other hand, is often interpreted as a rejection of the past by applying modern Western methodology that is based on the separation of church and state to transform non-western societies. ${ }^{13}$ Historically, western countries have not only disassociated themselves from the activities of the church but also rejected religion as a part of their worldly affairs and have opted for humanism and sciences to endorse the process of social and political transformation. The Muslim opposition to western secularism is due to the "nature of the Christianity" which "recognized the division of life into what belonged to God and what belonged to Caesar." ${ }^{14}$ For Muslims, this identity crisis often draws them closer to the religion into which they were socialized as children. Their religion acts as an anchor, alleviates their fears, and gives them a sense of stability, direction and faith in the future. Therefore, Islam, as both a historical

${ }^{11}$ Said Nursi, Risale-i-Nur: Flashes Collection specially the Fourth Flash, Istanbul: Sozler Publications, 2004, 35-43.

${ }^{12}$ Malcolm Waters, Globalization, London: Routledge, 1995, 127.

${ }^{13}$ Abdul Hayy Yahya Zalum: العولمة والز انسمالية (globalization and capitalism), Algeir: Book House, 1999, 118.

${ }^{14}$ Hirst and Thompson, Globalization in Question..., n. 19, especially 15. 
and an organic religion, is especially significant in the modernizing Muslim world. ${ }^{15}$

As modern globalization expands, spiritual and moral aspects become more marginalized in social life, almost all over the world. However, both economic and cultural aspects of globalization have their greatest effects on peoples of "developing countries", including the Arab World, because they are not the authors of globalization, rather, they simply live under the pressure of the rules set by others, namely, wealthy industrial influential economies.

In situations as such, hope decreases and gloom prevails as one repeatedly, when approaching information about globalization, reads statements that globalization posses eternity and it has inevitable consequences: "Globalization is a phenomenon that we cannot deny. All we can do is to accept it". ${ }^{16}$

Within the universal system of Islam human relations, coexistence and understanding are enhanced owing to the preservation of nations and groups identity. Despite the fact that Muslims are highly diversified in their cultural, social and linguistic features, they are united in the universality of the Islamic faith. Such as Islamic fundamentals as freedom, justice, equality, ethical and moral conducts are applied to all people in spite of their diversity. In doing so, the Islam rejects cultural homogeneity propagated by globalization. Allah Almighty says in the Quran: "O mankind! We created you from a single (pair) of a male and a female, and made you into nations and tribes that you may know each other (not that you may despise each other). Verily the most honored of you in the

\footnotetext{
15 Turki al Hamid, الثقاقة العربية فى عصر العولمة, Abu Dhabi: Malik bin Nabi Publications, 1998, 193.

${ }^{16}$ R.J. Barry Jones, Globalization and Interdependence in the International Political Economy: Reality and Rhetoric, London and New York: Pinter, 1995, 11.
} 
sight of Allah is (he who is) the most righteous of you". ${ }^{17}$

Nursi, in his work, offers a different concern through which unwelcomed globalization is counterbalanced by a union of faith and science, welcoming a universal approach not only to humanity but rather to both entities, seen and unseen, of the universe. He rejects neo-liberal, neo-colonial globalization and replaces it with a spiritual and scientific model of globalization. ${ }^{18}$

This is enough to say, that the new era of globalization is carrying in its portfolio a world view in which secularism does not only separate state and religion but also people's hearts and minds. It declares an unabridged gap between what is scientific, modern and civilized on one hand and what is religious, pious and virtuous on the other. In contrast, one who believes in the greatness of the One Creator sees everything else small and insignificant in comparison, unless it relates itself with the Divine unity or oneness of God.

Even when globalization affects some of one's own cultural aspects, it is not a big problem. The problem is when one's heart and belief get affected. When Nursi writes about some signs of the end of times he gives an example of an oppressor who wears a western hat and forces people to do the same. Nevertheless, because people remain guided this hat becomes guided and falls to earth in prostration. ${ }^{19}$ Thus, even if we can't avoid all the change that globalization may produce, we still have the ability to direct this change and connect it to the Creator.

Works contributions and Nursi's life proved his convictions. His life was a mixture of physical suffering and inner peace. The way he approached

${ }^{17}$ Al-Quran: al-H\}ujurat, verse 31.

${ }^{18}$ Graham Harrison, "Globalization" in Georgina Blakeley and Valerie Bryson (eds.), Contemporary Political Concepts, A Critical Introduction. London: Pluto Press, 2002.

${ }^{19}$ Ihsan Qasim Salihi, Nursi: Ash-shu'a'at, Cairo: Dar al-Neel, 2009, 14. 
the constant imprisonments for false accusations in different prisons can set the example for people who seek hope in the depth of anguish. His example will surely enlighten the hearts of those who really care and who are aware of the continuous process of globalization and fill them with hope and determination.

Both are crucial for the continuity and development of ideas, dreams, and actions. While for others, who are still sleeping right in the storm, Nursi's life rings the bell of alarm. In a world that suffers spiritual bankruptcy, Nursi's works are of utmost importance.

As a world system, globalization attempts to introduce a new set of relations having a multidimensional facet, which will affect not only the relations governing production and finance but also the main fundamentals of the social organization in Muslim societies. ${ }^{20}$

Globalization constitutes cultural, educational, scientific and technological dimensions that will have a direct impact on the patterns of conduct, of groups and nations, especially those concerning individual religious belief, identity, ideology, social relations, and lifestyle. However, if Muslims want to be part of the "global village", then they have to make considerable efforts to filter the materials passed into their own societies via modern technologies. They must ensure that the cultural identity and religious fundamentals are safeguarded against the invasion of Western secular products speared by globalization. In Risala-i Nur, Nursi made it very clear as far as the Islamic teaching and the implementation of the Sharia guidelines in the Muslim daily life. For Nursi the Oneness of Allah, the teaching of the Prophet, and other components of the Islamic worldview listed above are not subject to compromise in any form. He explains:

20 Tariq Mohammed, تحديات العولمد (Challenges of Globalization), Cairo: Muassasah Shabāb al-Jāmi'ah, 2008, 7. 
"And since the Prophet-hood of Muhammad (saws) and the Quranic revelation are like the spirit and intelligence of life, it may be said that their truth is as certain as the existence of life... If the light of the Prophet-hood of Muhammad (saws) was to depart from the universe, the universe would die. If the Quran was to depart, the universe would go mad, the earth would lose its head and its reason it would even strike its now unconscious head on a planet and Doomsday would occur."21

Being products of Western civilization, Nursi could have rejected the new global trends on the basis of their violation of Islamic ethical rules of conducts, particularly the sovereignty of Allah and His absolute power. Nursi is critical of Western civilization because of its orientation towards self-interest, conflict, and aggression.

\section{Counter globalization stance}

Nursi had always looked at the world as one unit glorifying the One Creator and testifying to His greatness. The universality he believed in came into contradiction with the universality that results from Globalization as it is generally understood and described.

As modern Globalization expands, spiritual and moral aspects become more marginalized in social life, almost all over the world. ${ }^{22}$ However, both economic and cultural aspects of Globalization have their greatest effects on peoples of "developing countries", including the Arab World, because they are not the authors of Globalization. Rather, they simply live under the pressure of the rules set by others, namely, wealthy industrial influential economies.

\footnotetext{
${ }^{21}$ Said Nursi, The Words, np.: The Light Inc., 2005, 203.

${ }^{22}$ Morris Berman, Dark Ages America, The Final Phase of an Empire, New York: WW. Norton and Company, 2006, 25-35.
} 
Moreover, people of economically less fortunate countries become themselves agents of Globalization in their own places. This is why the effects of Globalization are more harmful than those of colonialism. Globalization recruits its soldiers from among people it invades and expands to swallow the remnants of their culture and self-esteem by making them follow the model of those who are more powerful and who possess more. As Jalal Amin puts it describing how people fall in the trap of the industrially advanced: "Their will does weaken, their morals relax. Little by little, they backslide in their dedication to tradition... As much as they are able to, they ape the foreigners, and they are often ready to follow them in ridiculing the customs of their countrymen." ${ }^{23}$

Inflicting alien cultures and ways of life on people to be adopted and accepted is nothing novel. In situations as such, hope decreases and gloom prevails as one repeatedly, when approaching information about Globalization, reads statements such as Nelson's, speaking of its eternity and inevitable consequences: "Globalization is a phenomenon that we cannot deny. All we can do is accepting it" 24 .

This is what is called orthodox Globalization. However, many critical writers have discussed the reliability of such claims and have ended up offering certain scenarios for what they called counter Globalization. For example, Harrison in his article on Globalization argues in favor of four possible concerns within the academic writing which might serve to retrieve Globalization from the claws of the neo-liberal agenda, among which he mentions global civil society as an important concern that emerges when it is needed in order to promote social developmental and

\footnotetext{
${ }^{23}$ Jalal Amin, The Illusion of Progress in the Arab World, Cairo: the American University of Cairo Press, 2006, 11.

${ }^{24}$ Graham Harrison, "Globalization", in Georgina Blakeley and Valerie Bryson (eds.), Contemporary Political Concepts, A Critical Introduction, London: Pluto Press, 2002, 14.
} 
cultural considerations within the Globalization process. "Globalizing markets and capital must be recaptured by some social force and subject to some form of influence by societies." ${ }^{25}$

Nursi, in his work, offers a different concern through which unwelcomed Globalization is counterbalanced by a union of faith and science, welcoming a universal approach not only to humanity but rather to both entities, seen and unseen, of our universe. He rejects neo-liberal, neo-colonial Globalization and replaces it with a spiritual and scientific model.

In the Globalization process which can be derived from his work, hope is an essential element and its source is a rightly guided relationship with the Creator through which everything in life acquires its correct meaning. Human intellect, for example, can be a source of fear and anxiety. However, when it is guided by and connected to its Creator, it becomes a key by which humans can discover and uncover secrets of the universe and relate them to their source. Thus, they are able to comprehend the unity and the coherence through which they can live content and happy. ${ }^{26}$

Sadly enough, the new era of Globalization is carrying in its portfolio a world view in which secularism does not only separate state and religion but also people's hearts and minds. It declares an unabridged gap between what is scientific, modern and civilized on one hand and what is religious, pious and virtuous on the other. In contrast, one who believes in the greatness of the One Creator sees everything else small and insignificant in comparison, unless it relates itself with the Divine. ${ }^{27}$

Even when Globalization affects some of one's own cultural aspects, it is not a big task. The predicament is when one's heart and belief get

\footnotetext{
${ }^{25}$ Graham Harrison, "Globalization”..., 28.

${ }^{26}$ Said Nursi, Al-Shu'a'at, Ihsan Qasim Salihi (trans.), Cairo: Dar al-Neel, 2009, 18.

${ }^{27}$ Said Nursi, Al-Shu'a'at..., 22.
} 
affected. When Nursi writes about some signs of the end of times he gives an example of an oppressor who wears a western hat and forces people to do the same. Nevertheless, because people remain guided this hat becomes guided and falls to earth in prostration. ${ }^{28}$ Thus, even if we can't avoid all the change that Globalization may produce, we still have the ability to direct this change and connect it to the Creator.

Deeds do matter and Nursi's life proved his convictions. His life was a mixture of physical suffering and inner peace. The way he approached the constant imprisonments for false accusations in different prisons can set the example for people who seek hope in the depth of anguish. His example will surely enlighten the hearts of those who really care and who are aware of the continuous process of Globalization and fill them with hope and determination. Both are crucial for the continuity and development of ideas, dreams, and actions. While for others, who are still sleeping right in the storm, Nursi's life rings the bell of alarm. In a world that suffers spiritual bankruptcy, Nursi's works are of utmost importance.

Some Arab States, Syria among them, proud of their cultural heritage, are fighting unrelentingly to preserve it in the face of an overwhelming wave of changes which have been brought upon them. Working hard to keep the language and traditional ways of living has been fruitful in some areas and less so in others. For example, Arabization of school curriculum at all educational levels has produced new generations fluent in Arabic but poor in other languages.

In the light of the improving relations between Syria and Turkey, people in these countries increasingly derive lessons from each other's experiences, share their mutual Islamic heritage and try to find new ways out of the trap that aims at melting everything in one pot which serves

\footnotetext{
28 Said Nursi, Al-Shu'a'at..., 104.
} 
only a few of them. During a conference held in Damascus just a few years ago of beginning the Syrian crisis, high-lightening the extra ordinary common history and mutual relations, in which the then Syrian Minister of Culture had praised Turkey for turning its interest to the Muslim World, in which it deserves the position of the leader. This was proved by the fact of several Turks who chose to be martyrs as an expression of loyalty to the case of Palestine. Though, the scenario has totally changed now, relations the between the two countries are no more as happened to be. Undoubtedly, had there been the associations of both states the state of affairs would have been some things else.

Trust in one's partners is very crucial for the success of this project. Turkey is now in the process of reclaiming its position in the Muslim World in general and the Arab World in particular. I think it is proper to assume that this particular moment can be the beginning of an era of a religious Globalization through which Globalization from below is able to rectify and guide the steps of Globalization from above.

\section{Conclusion}

In wrapping up, the model that is offered in Nursi's works for a globalized world is twofold: it rejects the recent orthodox globalization and calls for another kind of guided enlightened globalization for the establishment of which hope, belief, knowledge and determination are essential elements. These elements are illustrated and discussed throughout Nursi's works and embodied in the changes they brought to present day Turkey.

In the globalization process which can be derived from his work, hope is an essential element and its source is a rightly guided relationship with the Creator through which everything in life acquires its correct meaning. Human intellect, for example, can be a source of fear and anxiety. However, when it is guided by and connected to its Creator, it becomes a 
key by which humans can discover and uncover secrets of the universe and relate them to their source. Thus, they are able to comprehend the unity and the coherence through which they can live content and happy.

As far as indigenous cultures vis-a-vis globalization is concerned, Nursi's actions ideally fit the principle of "thinking globally while acting locally," as Nursi promotes both modernization and progress while maintaining the cultural identity of Muslim individuals and the broader society.

\section{Bibliography}

Al-Alizi, Zulkifl Zainul Abidin. دار الاتبار للطباعة للنشر .الانس الفكرية لدعوة الاصلاح, 2002.

Amin, Jalal. The Illusion of Progress in the Arab World. Cairo: the American University of Cairo Press, 2006.

Berman, Morris. Dark Ages America, the Final Phase of an Empire.New York: WW. Norton and Company, 2006.

El-Dabbagh, Adib Ibrahim. شُركة سوزلز للنثر بسيد النورسي رجل الإيمان في محنة الكفز والطنيان, 2003.

Nursi, Badiuzzaman Said. Risala-i-Nur: Flashes Collection. Istanbul: Sozler Publications, 2004.

Esposito, John L., "Religion and Global Affairs: Political Challenges," SAIS Review, Vol. 18, No. 2 (1998).

Al-Hamid, Turki. الثقافة العربية في نعصر العولمة. Abu Dhabi: Malik bin Nabi Publications, 1998.

Harrison, Graham, "Globalization" in Georgina Blakeley and Valerie Bryson (eds.), Contemporary Political Concepts, A Critical Introduction. London: Pluto Press, 2002.

Jones, R.J. Barry. Globalization and Interdependence in the International Political Economy: Reality and Rhetoric. London and New York: Pinter, 1995. 
Markham, Ian S. and Ozdemir, Ibrahim. Globalization, Ethics and Islam: the Case of Badiuzzaman Said Nursi. np.: Ashgate Publishing, Ltd., 2005.

Markham, Ian S. Engaging with Badiuzzaman Said Nursi: a Model of Interfaith Dialogue. np.: Ashgate Publishing, Ltd., 2009.

Martin, Peter, Hans and Harold Showman, فنخ العولمة (Piercing Globalization). Kuwait: Dār al-Ma'rifa, 2003.

Mohammed,Tariq. تحديات العولمة (Challenges of Globalization). Cairo: Muassasah Shabāb al-Jāmi'ah, 2008.

Nursi, Badiuzzaman Said. Risala-i-Nur: Flashes Collection specially the Fourth Flash. Istanbul: Sozler Publications, 2004.

Nursi, Badiuzzaman Said. The Words. np.: The Light Inc., 2005.

Rabi, Ibrahim Abu. Spiritual Dimensions of Badiuzzaman Said Nursi's Risala-i Nur. Albany: State University of New York Press, 2008.

Robertson, Roland. Globalization, Social Theory and Global Culture. London: Sage Publication, 1997.

Salihi, Ihsan Qasim. Nursi: Ash-shu'a'at. Cairo: Dar al-Neel, 2009.

Uwais, Abdul Halim. شركة سوزلر للثشر, .رجل الإيمان والتجديث في وجه العلمائية والتمليد , 2003: بديع الزمان سعيد النورسىى.

Waters, Malcolm. Globalization. London: Routledge, 1995.

Zalum, Abdul Hayy Yahya, العولمة والز اسمالية (globalization and capitalism). Algeir: Book House, 1999. 